\title{
NICHOLAS KALDOR'S LIFE AND INSIGHTS INTO THE APPLIED ECONOMICS OF GROWTH
}

Anthony Philip THIRLWALL

This article celebrates the life and work of the Hungarian economist Nicholas Kaldor, and particularly his emphasis on industrial structure and the role of demand in determining the growth performance of nations.

Keywords: Kaldor's growth laws, export-led growth, cumulative causation

JEL classification indices: 014, 040, 047

\section{THE MILESTONES OF KALDOR'S LIFE}

When Nicholas Kaldor arrived in the United Kingdom from Berlin in 1927 to enrol as a student at the London School of Economics (LSE), he could never have imagined that he would later become one of the most original economists of the $20^{\text {th }}$ century, and ultimately join the ranks of the British establishment as a member of the House of Lords as Baron Kaldor of Newnham in the City of Cambridge. The journey was long and arduous, but highly successful. He was supported by a happy family life. In 1934, he married Clarissa Goldschmidt and was the father of four daughters.

Anthony Philip Thirlwall, Professor of Applied Economics at the Department of Economics, Keynes College, University of Kent, U.K. E-mail: A.P.Thirlwall@kent.ac.uk 
I knew Kaldor well in the last years of his life between 1979 and 1986. In the mid-1970s, I had already decided that I would write an intellectual biography of him - I found him such an original and interesting economist, and decided there was a Kaldorian economics to be written. In 1979, I spent a sabbatical term in King's College, Cambridge. I attended Kaldor's lectures; I talked to him, and finished reading the whole of his published work - over 250 articles and books. Then, in the academic year 1985-1986, I spent a whole year in Cambridge, working in his house in Adams Road to sort out his papers; read his correspondence with other economists, and to interview him extensively about his ideas and events of long ago. My biography of him was published in $1987 .{ }^{1}$

His background was Hungarian; he was born in Budapest in 1908. His father was a distinguished lawyer, ${ }^{2}$ and his mother an accomplished linguist. He attended the famous Gymnasium of Excellence (Mintagimnázium, as it was called at that time in Hungarian), the home of other distinguished academics such as Michael Polanyi, Edward Teller, Leo Szilard, Theodore von Karman, Nicholas Kurti, and Thomas Balogh. Kaldor excelled as a student at the LSE, graduating with a first class honours degree in economics in 1930, and became the favourite pupil of Lionel Robbins, who dominated the Economics Department at the LSE at this time, and later became its Director. Kaldor in his early career, under the influence of Robbins, was wedded to the Austrian school of thought, and his first published paper examined the Economic Problems of the Danubian States from an Austrian perspective (1932). He was acquainted with Friedrich von Hayek, who had been brought to the LSE by Robbins in the early 1930s as a counterweight to the growing influence of Cambridge economics, but Kaldor was one of the first LSE economists to be converted to the Keynesian revolution, and fell out with both Hayek and Robbins. During his years at the LSE before World War II, Kaldor made major contributions to the theory of the firm $(1934,1935)$, to capital theory (1937), to trade cycle theory (1940), to welfare economics (1939a), and to the Keynesian revolution itself (1939b).

Kaldor and Keynes became good friends in the late 1930s. During the war, he contributed significantly to Keynes' thinking about national income accounting and war finance. In the field of public policy, he made major contributions to the two Beveridge Reports: the first on Social Insurance in 1942 and the second on Full Employment in a Free Society in 1944. Kaldor's contribution to the latter Report, contained in the now-famous Appendix C, was to calculate the revenue and expenditure implications of the government pursuing a fiscal policy to main-

There are two more intellectual biographies of Kaldor: Targetti (1992) and King (2009).

For more on him, see the autobiography of János Kornai (2007), whose father was also a lawyer and happened to know Gyula Kaldor personally (Editor's note). 
tain full employment, and in doing so, he developed what was virtually the first mini-econometric model of the UK economy. As his reputation grew as an applied economist and policy adviser, he received numerous offers to participate in expert advisory bodies. The first in 1945 was to act as Chief of the Planning Staff of the US Strategic Bombing Survey of Germany under the overall direction of John Kenneth Galbraith. In 1946, he served as an adviser to the Hungarian government on its new Three Year Plan, ${ }^{3}$ and in 1947, he was invited to assist Jean Monnet at the French Commissariat General du Plan in preparing a plan for the financial stabilisation of France. Then came the invitation from Gunnar Myrdal to become the first Director of the Research and Planning Division of the newly created Economic Commission for Europe (ECE) in Geneva, with the specific task of preparing an annual Economic Survey of Europe. In Geneva Kaldor also became involved in several special assignments, including acting as an adviser to the UN Technical Committee on Berlin Currency and Trade established in the winter of 1948-1949 in an attempt to end the Soviet blockade of Berlin. As a Member of the UN Expert Committee, he prepared a report on National and International Measures for Full Employment in 1949. This widely-acclaimed report was largely drafted by Kaldor, and such was the impact of the Report that he was asked by the Council of Europe to chair a Working Party on how the recommendations of the Report might apply to Europe.

Kaldor was never appointed to a Chair at the LSE and resigned his position at the LSE in 1947 when he went to Geneva. He stayed there until 1949 when he was offered a Lectureship in Economics at Cambridge University and a Fellowship at King's College, thus following in the footsteps of Keynes, who had died in 1946. Kaldor was to stay in Cambridge for the rest of his life. In many ways, he took on the mantle shed by Keynes. They had several characteristics in common. Both treated economics as a moral science - as a branch of ethics - as a means of making the world a more civilised place in which to live. Both had a strong intuition and an insistence that a scientific theory should follow the inductive method with theory based on realistic assumptions and conforming to the facts. Both were adept at devising new and ingenious schemes to improve the functioning of economies. Both were inveterate letter-writers to the press with an urge to protest. Keynes was a liberal and Kaldor a socialist, but both shared the same vision of the role of government in economic affairs, particularly the need to stabilise the economy to ensure full employment of resources if private effective demand for goods and services was deficient. Both Keynes and Kaldor had the ear of politicians, and were influential advisers at both home and abroad.

For a detailed account of this advisory work, see Mommen (2017) in this Special Issue (Editor's Note). 
Kaldor sat on the Royal Commission on Profits and Taxation in the early 1950s, writing an influential Minority Report. He gave influential advice to the Radcliffe Committee on the Workings of the Monetary System in the late 1950s, and then when the Labour Party came to power in 1964, he was appointed Special Adviser to the Chancellor of the Exchequer. He was responsible for many tax reforms in the UK, including corporation tax and a capital gains tax, and an ill-fated Selective Employment Tax which attempted to shift labour from the service sector into manufacturing industry.

Kaldor's academic life as an economist flourished in Cambridge in the 1950s and 1960s. He became joint architect, along with Joan Robinson, Richard Kahn, and Luigi Pasinetti, of what came to be called "Cambridge growth and distribution theory", which challenged the orthodox neoclassical approach to economic growth and to the distribution of income between wages and profits based on marginal productivity theory. A spate of papers flowed from his pen in those halcyon days (Kaldor 1956, 1957, 1961; Kaldor - Mirrlees 1962). At the same time, he became one of the world's major tax experts, and championed the idea of an Expenditure Tax (1955) as the fairest way of raising tax revenue - although not without its practical difficulties. His tax expertise led to invitations from all over the world to advise on tax reform starting with India in 1956, and then Ceylon (now Sri Lanka) in 1958, Mexico in 1960, Ghana in 1961, British Guiana in 1961, Turkey in 1962, Iran in 1966, and Venezuela, 1976 (1980b).

While a government adviser in the UK in the 1960s, his attention turned to the applied economics of growth, and to the causes of the slow rate of growth of the United Kingdom compared with continental Europe. His views formed the basis of his Inaugural Lecture in Cambridge in 1966 in which he explained why manufacturing industry is the engine of growth and that the root of Britain's malaise was the slow rate of growth of its manufacturing sector - apparently starved of labour, unlike Europe which still had large reserves in agriculture. Manufacturing growth is important for two main reasons: first, because it induces productivity growth within manufacturing due to static and dynamic returns to scale (Verdoorn's Law), and second, because as more labour is absorbed into manufacturing, productivity rises in the non-manufacturing sector which has surplus labour with the marginal product of labour less than the average (diminishing returns). Kaldor repeated his ideas in the Frank Pierce Memorial Lectures at Cornell University in the same year (1967), but with some subsidiary propositions relating to developing countries. First, as labour is absorbed from the agricultural sector, growth will slow. Secondly, the major determinant of manufacturing growth in the early stages of development is the prosperity of agriculture, but in the later stages of development, it is export growth. Export growth can set up a virtuous circle of growth via induced productivity growth 
(the Verdoorn effect). Fast export growth leads to fast output growth; fast output growth leads to fast productivity growth; fast productivity growth makes countries more competitive, and maintains the fast growth of exports. It was this export-led growth model that he fully articulated (although in purely verbal form) to the Scottish Economic Society in 1970, and published as "The Case for Regional Policies"- one of his most cited papers. Kaldor's growth laws have been extensively tested across countries and regions with broad support (for a partial survey, see Thirlwall 2013).

The Labour Party lost power in 1970 and Kaldor had more time to campaign on two major public issues which concerned him greatly. The first was the acceptance by economists and policy-makers of the doctrine of monetarism, which had spread with the virulence of a plague from the University of Chicago under the influence of Milton Friedman to infect policy thinking at the highest level in the UK. The second concerned the UK's entry into the Common Market (European Union). With regard to monetarism, Kaldor led the intellectual assault worldwide against the monetarist view that inflation is always and everywhere a monetary phenomenon in a causal sense caused by excessive government expenditure financed by money creation. On the contrary, argued Kaldor, because money consists largely of credit, and credit only comes into existence if it is demanded, money is endogenous to an economy, not causal in the determination of output and prices. The major cause of inflation, at least in mature industrial countries, is rising wages and other costs. Kaldor could find no evidence in the UK, or across countries, of any relation between the size of countries' budget deficits and measures of broad money (1980). Kaldor lost the battle against monetarism in the UK, but won the war because the doctrine of monetarism is now dead.

On the issue of the UK joining the Common Market, Kaldor was highly sceptical of the alleged dynamic benefits stemming from a larger market for the export of goods and services. He argued that because imports are likely to grow faster than exports, as trade barriers come down, the UK would need to deflate the economy to preserve balance of payments equilibrium, and this would slow growth. On top of this, the budgetary contribution would be huge; the price of food would rise leading to wage increases, and Britain would be letting down the Commonwealth countries which had a preferential access to the UK market. The referendum in 1975 against joining the Common Market was lost, but Kaldor appears to have been correct in his predictions. The dynamic benefits of having become a member of the EU are nowhere to be seen. If anything, productivity growth has been slower post-1975 than pre-1975 (although other factors have also been at work).

The Labour Party regained power in 1974, and again Kaldor was appointed as a Special Adviser to the Chancellor of the Exchequer - this time, Denis Healey. 
The British economy was in crisis, and Kaldor recommended import controls as a temporary expedient, which were rejected. In 1976, Kaldor resigned from his government position, never to return. Instead, he continued to criticise government economic policy, and even more vehemently when Mrs Thatcher came to power in 1979, armed with the ideas and policies of her neo-liberal heroes: Friedrich von Hayek and Milton Friedman. Laissez-faire, laissez-passer became the order of the day with exchange rates allowed to float to dangerously over-valued levels, manufacturing industry allowed to crumble, and virtually all controls removed from the financial sector (the "big bang"), which ultimately led to the financial crisis of 2007 and the longest recession in the UK's recorded history. Kaldor made trenchant critical speeches in the House of Lords, which were later published as a book, The Economic Consequences of Mrs Thatcher (in 1983), reminiscent in tone and indignation to Keynes's magnificent polemic The Economic Consequences of the Peace (Keynes 1919).

In the late 1970s and early 1980s, Kaldor's theoretical mind turned to the topics of the determination of world economic growth and its fluctuations, and to a critique of equilibrium theory in economics. With regard to world economic growth, he developed a two-sector (closed economy) model of agriculture and industry in which there is reciprocal demand for each sector's product and where the role of the terms of trade between industrial goods' prices and primary product prices is to bring into balance the supply of, and demand for, each sector's output. If primary product prices are too high, the growth of the world economy becomes supply constrained because industry's capacity to produce is impaired, while if primary product prices are too low, the growth of the world economy becomes demand constrained because the primary producing sector does not have the purchasing power to buy industrial goods. Kaldor, like Keynes before him, wanted multilateral institutions to stabilise the terms of trade of primary commodities to prevent wide and excessive fluctuations which can lead to stagflation in the world economy. Keynes, during wartime, had proposed a scheme for what he called "Commod-Control" to keep the prices of commodities within a certain margin of an agreed price. At Bretton Woods, Keynes had proposed a world central bank with the power to create money for collectively agreed purposes, one of which would have been to buy up commodities in surplus. Kaldor wanted Special Drawing Rights (SDRs) issued by the IMF to be used for this purpose. In the long-run, in Kaldor's two-sector model, the growth of the world economy is determined by the rate of growth of land-saving innovations in agriculture as an offset to diminishing returns. Without innovation in agriculture, the growth of the agricultural sector would slow down, reducing the demand-growth for industrial goods. Kaldor never formalised his two-sector model, but attempts have been made by Targetti (1985) and Thirlwall (1986). 
Kaldor's attack on equilibrium theory had three main strands. ${ }^{4}$ The first was methodological, the second related to the lack of realism concerning the role of markets and how they function in practice, and the third relates to the implications of the neglect of increasing returns. His assault gathered momentum in the 1970s with provocative papers on "The Irrelevance of Equilibrium Economics" (1972) and "What is Wrong with Economics" (1975), and culminated in his Okun Memorial Lectures on Economics without Equilibrium (1985) and his 1984 Mattioli Lectures on Causes of Growth and Stagnation in the World Economy (1996). At the methodological level, Kaldor was strongly against the deductive method of building models on a priori assumptions without any firm empirical base. This critique paralleled the disquiet that many economists had been expressing for a long time concerning the use of mathematics in economics, which, for the sake of scientific precision, invariably substitutes elegance for relevance. With regard to the lack of realism concerning the functioning of markets, his major objection was the emphasis on the principle of substitution and the allocative function of markets to the neglect of the creative function of markets and the complementarity between activities. Finally, there is the problem for equilibrium theory of increasing returns. Marshall, Sraffa, Hicks, among the great economists, all recognised this difficulty. Increasing returns, based on the division of labour, lay at the heart of Adam Smith's vision of economic progress as a self-generating process, and Kaldor used to joke that he thought economics went wrong after Chapter 4, Book 1, of the Wealth of Nations (Smith 1776), when Smith dropped the assumption of increasing returns and the foundations of equilibrium theory were laid. The concept of increasing returns lay virtually dormant until Allyn Young, Kaldor's early teacher at the LSE, revived it in a powerful but neglected paper in 1928 entitled "Increasing Returns and Economic Progress" (Young 1928). Kaldor kept harping back to Young's paper. The implications and consequences of increasing returns for how economic processes are viewed are indeed profound and far-reaching. First, what is the meaning of "general equilibrium" if increasing returns causes everything in the equilibrium system to change - resource availabilities, technology, tastes, prices, and so on? Secondly, once increasing returns are admitted, the concept of an optimum allocation of resources loses its meaning since the position of the production possibility curve itself depends on how resources are allocated. Thirdly, increasing returns undermine the notion that at any moment of time output must be resource constrained. Finally, if supply and demand interact in the presence of increasing returns, as described by Young, many of the treasured theorems of equilibrium economics become untenable, e.g. factor price equalisation, the equilibrating role of labour and capital movements between re-

For a further analysis of this debate, see Mihalyi (2017) in this Special Issue (Editor's Note). 
gions, growth rate convergence between regions and between countries, and so on. Kaldor admitted that as a young man, he was caught in the equilibrium trap (1986), but he did eventually escape. ${ }^{5}$

In 1969, the first year of the Nobel Prize in Economics, the Financial Times ${ }^{6}$ reported that Kaldor was on a short-list of 10 candidates for the honour, including Milton Friedman, Paul Samuelson, James Meade, Francois Perroux, and the Russian Leonid Kantorovich, but he was never to receive it. The Economist newspaper once described him, ${ }^{7}$ however, as the best known economist in the world not to have received the Nobel Prize; and I think there is some truth in this.

\section{STRUCTURE AND DEMAND MATTER FOR ECONOMIC GROWTH - OR WHY I BECAME A KALDORIAN}

Now will describe how I became a Kaldorian, as a prelude to discussing Kaldor's insights into the applied economics of growth in which the structure of production and demand matter for the long run growth of economies, in contrast to orthodox neoclassical theory which deals with a one-good economy in which structure and demand do not matter, and in which supplies of factors of production and technical progress are exogenously given.

What attracted me to Kaldor first of all was not his growth and distribution models of the 1950s, which were purely theoretical, but his "Inaugural Lecture" in Cambridge in 1966 entitled Causes of the Slow Rate of Economic Growth of the United Kingdom, followed by his Frank Pierce Memorial Lectures at Cornell University, published as Strategic Factors in Economic Development (1967). In these lectures he gives a structural explanation of why growth rates differ between countries, singling out manufacturing industry as "the engine of growth". In the United Kingdom's case, he attributed slow growth to what he called "premature maturity", by which he meant the exhaustion of the supplies of labour from agriculture to provide labour for manufacturing industry before a high level

5 While searching in Kaldor's house, I found a complete typed set of lecture notes that Kaldor had taken from Young in 1928. They are interesting because Young was Edward Chamberlin's $\mathrm{PhD}$ supervisor in Harvard, and Young was teaching monopolistic competition theory at the LSE long before Chamberlin's book on monopolistic competition was published in 1933. The lectures are published in the Journal of Economic Studies in 1990 edited by Roger Sandilands.

6 August 8, 1969.

7 January 20, 1979. A well-informed, scholarly book on the Nobel Prize in economics lists four further British economists - A. Atkinson, P. Dasgupta, R. Harrod, and J. Robinson - who were also not awarded (Offer - Söderberg 2016: 135). (Editor's note) 
of productivity in industry had been reached - in contrast to other European countries. As a young Lecturer at the University of Kent looking for an intellectual home, these lectures struck a chord, and I incorporated the ideas into my own lecture notes on growth and development theory. I now had a counterweight to the unsatisfactory assumptions of neoclassical growth theory. I believed him to be wrong that the UK's fundamental growth problem was a shortage of labour for manufacturing industry (and Kaldor soon changed his mind on this), but not on his emphasis on the fact that the production (and demand) characteristics of industry are different from those of land-based activities and services - namely that manufacturing industry is characterised by increasing returns (static and dynamic returns to scale), while most activities outside of manufacturing are subject to constant or diminishing returns. Kaldor's view, which he never changed, was that it is not possible to understand growth rate differences between countries, or differences in the levels of development between countries, without making this fundamental distinction between what types of activities countries specialise in.

Out of these 1966 lectures came three growth laws. Firstly, manufacturing is the engine of growth in a causal sense - not simply because manufacturing output is a part of total output, i.e.

$$
g_{g d p}=f_{1}\left(g_{m}\right) \quad f_{1}^{\prime}>0
$$

where $g_{g d p}$ is the growth of GDP and $g_{m}$ is the growth of manufacturing output. This is testable. The reason manufacturing is the engine of growth is that it induces productivity growth both within manufacturing itself, and also outside the manufacturing sector. This leads to the second and third laws.

The second law is that manufacturing output growth induces labour productivity growth within manufacturing because of static and dynamic returns to scale. Static economies refer to economies of scale, and dynamic economies refer mainly to learning by doing and embodied technical progress as more capital is accumulated in the process of growth, i.e.

$$
p_{m}=f_{2}\left(g_{m}\right) \quad f_{2}>>0
$$

where $p_{m}$ is productivity growth in manufacturing. This second law is often referred to as Verdoorn's Law after a paper published by P. J. Verdoorn (1949) showing this relationship across a sample of Eastern European countries. Interestingly, Verdoorn was one of Kaldor's staff in the Research and Planning Division of the ECE in the late 1940s, but no further research was done on the "law" for 17 years until Kaldor revived it, and only one reference was made to it by Arrow in his classic paper on the economics of learning by doing (Arrow 1962). Since 1966, 
there has been a mass of research on Verdoorn's Law - all supportive - although some studies also find a Verdoorn effect in some activities in the service sector. ${ }^{8}$

The third law states that manufacturing growth induces productivity growth outside of manufacturing because if there are diminishing returns to labour, with the marginal product of labour less than the average product, a reduction in labour will raise the average product. i.e.

$$
p_{n m}=f_{3}\left(g_{m}\right) \quad f_{3}^{\prime}>0
$$

where $p_{n m}$ is the growth of productivity in non-manufacturing.

All three laws have been extensively tested and have strong empirical support across developed countries, developing countries, and across regions within countries. For example, see Hansen - Zhang (1996) for a study across the regions of China, Necmi (1999) for a panel data study across several developing countries, Libanio (2010) for a study across the countries of Latin America, and Wells - Thirlwall (2003) for a study across the countries of Africa. Structure matters for economic performance.

These results, of course, have policy implications particularly for poor countries which want to accelerate economic development for the reduction in poverty. What is the role of the State in promoting manufacturing industry? What is the role of industrial policies? Is there a case for protection? If so, should it be by tariffs, subsidies, or selected credit to new industries? The late development economist, Ajit Singh, once said to me that as a student of Kaldor, Kaldor taught him three things: first, developing economies must industrialise, second, they can only industrialise by protection, and third, if anyone says otherwise, they are being dishonest.

But what drives manufacturing output growth in the first place? In Kaldor's thinking, it is agricultural growth in the early stages of development and export growth in the later stages. These are the two fundamental sources of autonomous demand for manufacturing output to offset leakages of income from the manufacturing sector for the purchase of food from agriculture and imported inputs into industry. This thinking is the basis of his two-sector model of industry and agriculture in which the terms of trade play a crucial role. If the industrial terms of trade are "too high", the growth of industry is demand constrained because the agricultural sector lacks the purchasing power to buy manufactured goods. If the industrial terms of trade are "too low", industrial growth is supply constrained because industry does not have the profits to invest. Kaldor lectured on this model for many years in Cambridge, and it formed part of his Hicks Lecture (1986) and

8 In 1999, there was a conference in Genoa celebrating the $50^{\text {th }}$ anniversary of Verdoorn's paper, out of which came a book: McCombie (2003). 
his 1986 Mattioli Lectures (1996). Thirlwall (1987) and Targetti (1985) attempt to give a more formal structure.

The second paper which struck an intellectual chord was Kaldor's address to the Scottish Economic Society in 1970 entitled "The Case for Regional Policies". Here, at the regional level, he switches focus from the structure of production in a closed economy to the role of exports in an open regional context in which the growth of exports is considered the major component of autonomous demand (to which other components of demand adapt), which sets up a virtuous circle of growth working through the Verdoorn effect - similar in character to Gunnar Myrdal's theory of circular and cumulative causation in which success breeds success and failure breeds failure (Myrdal 1957). This is one of his challenges to equilibrium theory that free trade and the free mobility of factors of production will necessarily equalise economic performance across regions or countries. Structure still matters, but it is now the demand characteristics of goods that matter most, not the supply characteristics of production. It makes a difference to economic performance of regions or countries whether they produce and export cabbages or computers. The model Kaldor put forward was a purely verbal one, but Dixon and I formalised it in a paper entitled "A Model of Regional Growth Rate Differences on Kaldorian Lines" (Dixon - Thirlwall 1975). The model has four equations that can be solved for the equilibrium growth rate. The first makes output growth a function of export growth (and the more specialised regions are, the greater the importance of exports). The second equation makes export growth depend largely on a region's changing price competitiveness and the growth of income outside the region. The third equation gives the rate of change of a region's prices as the difference between wage growth and productivity growth. Lastly, labour productivity growth is partly determined by the growth of output itself through static and dynamic increasing returns, captured by Verdoorn's Law. In equation form, the propositions may be specified as ( $t$ is a time subscript):

$$
g_{t}=\Upsilon\left(x_{t}\right)
$$

where $g_{t}$ is the growth of regional output, and $x_{t}$ is the growth of exports.

$$
x_{t}=\eta\left(p_{d t}-p_{f t}\right)+\varepsilon\left(z_{t}\right)
$$

where $p_{d t}$ is the growth of domestic prices, $p_{f t}$ is the growth of foreign prices measured in a common currency, $z_{t}$ is the growth of income outside the region, $\eta$ $(<0)$ is the price elasticity of demand for exports, and $\varepsilon(>0)$ is the income elasticity of demand for exports.

$$
p_{d t}=w_{t}-r_{t}
$$

where $w_{t}$ is the growth of wages, and $r_{t}$ is the growth of labour productivity. 


$$
r_{t}=r_{a t}+\lambda\left(g_{t}\right)
$$

where $r_{a t}$ is autonomous productivity growth and $\lambda$ is the Verdoorn coefficient.

Substitution of equation (7) into (6) and the result into (5) and (4) gives the equilibrium growth of regional output as:

$$
g_{t}=\frac{\Upsilon\left[\eta\left(w_{t}-r_{a t}-p_{f t}\right)+\varepsilon\left(z_{t}\right)\right]}{1+\Upsilon \eta \lambda} .
$$

Remembering that $\eta<0$, growth is shown to be negatively related to domestic wage increases, but positively related to foreign price increases and autonomous productivity growth. Growth is also positively related to the growth of external demand and the size of the Verdoorn coefficient. It is the Verdoorn coefficient $(\lambda)$ that makes the model "circular"; but whether growth is "cumulative" (i.e. departs further and further away from equilibrium) depends on the behaviour of the model out of equilibrium. To make the model dynamic, and to assess whether it is stable or not, it is sufficient to put a one-period time lag into any of the equations. Dixon and I chose to put a one-period lag in the export growth equation giving $x_{t}=\eta\left(p_{d t-1}-p_{f t-1}\right)+\varepsilon\left(z_{t-1}\right)$. Successive substitution as before gives a first order difference equation, of which the general solution to the homogenous part is:

$$
g_{t}=A(-\Upsilon \eta \lambda)^{t}
$$

where $A$ is the initial condition. Whether the model is stable or not out of equilibrium depends on the value of $(-\Upsilon \eta \lambda)$. If exports grow twice as fast as output, $\gamma=$ 0.5 . A typical value for the Verdoorn coefficient $(\lambda)$ is 0.5 . In this case, the price elasticity of demand for exports $(\eta)$ would have to exceed minus 4 for $(-\Upsilon \eta \lambda)>1$, and for there to be "explosive" growth. It is rare to find aggregate price elasticities of demand for exports as high as that, but in any case we do not observe in practice regional growth rates diverging - only levels of per capita income. This suggests that regional growth rate differences that are observed are associated with differences in regions' equilibrium growth rates largely determined by differences in the income elasticities of demand for exports $(\varepsilon)$ associated with regional differences in the structure of production and trade: whether regions specialise in primary production or manufactured goods and sophisticated services.

In fact, if the Verdoorn effect is ignored, and it is assumed that regional competitiveness stays constant, equation (8) becomes:

$$
g_{t}=\varepsilon\left(z_{t}\right)
$$


Regional growth is determined by the growth of income outside the region and by the types of goods exported reflected in the income elasticity of demand for exports.

It is a weakness of the original Kaldor model, however, that there is no balance of payments constraint. In practice, the growth rate in equation (10) may cause import growth to be faster than export growth which is unsustainable in the long run. A balance of payments constraint is easily incorporated, however (Thirlwall - Dixon 1979). The export growth equation (5) can be modified to include the rate of change of the exchange rate $(e)$ :

$$
x_{t}=\eta\left(p_{d t}-p_{f t}-e_{t}\right)+\varepsilon\left(z_{t}\right)
$$

We can then add an equation for the rate of growth of imports $(m)$ :

$$
m_{t}=\psi\left(p_{f t}-p_{d t}+e_{t}\right)+\pi\left(g_{t}\right)
$$

where $\psi(<0)$ is the price elasticity of demand for imports and $\pi(>0)$ is the income elasticity of demand for imports.

Setting equation (11) equal to (12), and substituting equations (6) and (7) into (11) gives the balance of payments equilibrium growth rate of:

$$
g_{t}=\frac{(1+\eta+\psi)\left[w_{t}-r_{a t}-p_{f t}-e_{t}\right]+\varepsilon z_{t}}{\pi+\lambda(1+\eta+\psi)} .
$$

If there is no Verdoorn effect $(\lambda=0)$, and relative prices measured in a common currency remain unchanged, equation (13) collapses to:

$$
g_{t}=\varepsilon z / \pi \text {. }
$$

Equation (14) is the classic centre-periphery model of Prebisch (1959), where the growth of one region or country relative to others $\left(\mathrm{g}_{\mathrm{t}} / \mathrm{z}_{\mathrm{t}}\right)$ is equi-proportional to the ratio of the income elasticity of demand for exports and imports $(\varepsilon / \pi)$. Equation (14) can also be shown to be the dynamic analogue of the static Harrod trade multiplier, $Y=X / \mathrm{m}$, where $Y$ is the level of output, $X$ is the level of exports, and $m$ is the marginal propensity to import (Harrod 1933; Thirlwall 1982). Kaldor first revived the Harrod trade multiplier in a letter to The Times newspaper (March 15, 1977), and argued that it is more important than Keynes's investment multiplier for understanding the pace and rhythm of economic growth in an open economy (Kaldor 1981). Or, to put it another way, it is more difficult for a country to rectify an import-export gap than it is to rectify a savings-investment gap.

Of course, regions within countries do not experience classic balance of payments problems in the sense that an exchange rate comes under pressure, but if import growth exceeds export growth and capital transfers (domestic and in- 
ternational) do not finance the difference, the balance of payments constraint will show up in slow growth and rising unemployment. Regional problems are balance of payments problems (Thirlwall 1980) as we witness in the peripheral countries of the eurozone today. A large part of the sovereign debt and private banking crisis in the eurozone stems from the heavy borrowing by the deficit countries of Greece, Spain, Portugal, and Italy from the surplus countries of Germany, the Netherlands, and Austria (Priewe 2012). The free movement of capital facilitates the financing of deficits, but exposes countries to adverse internal and external macroeconomic shocks if the flows are debt-creating.

\section{AN ALTERNATIVE EXPLANATION OF KALDOR'S FIRST LAW OF GROWTH}

From the two canonical models of Kaldor outlined above, it might be said that there is an uneasy connection between the closed economy model of growth rate differences based on the structure of production, and the open economy model in which export growth is the driving force. There is an uneasy connection, but it is easy to see that manufacturing as the engine of growth is also a reduced form of export-led growth in which GDP growth is a function of export growth, but export growth is a function of manufacturing output growth. In other words:

$$
\begin{gathered}
g_{g d p}=a_{1}+b_{1}(x) \\
x=a_{2}+b_{2}\left(g_{m}\right)
\end{gathered}
$$

and substituting (16) into (15) gives:

$$
g_{g d p}=\left(a_{1}+b_{1} a_{2}\right)+\left(b_{1} b_{2}\right) g_{m} .
$$

Kaldor's first law of growth is a reduced form of two structural equations and depends on the elasticity of GDP growth with respect to export growth $\left(b_{1}\right)$, and the elasticity of export growth with respect to manufacturing output growth $\left(b_{2}\right)$. A colleague and I have tested these relationships across a sample of 89 developing countries over the period 1990-2011 (Pacheco-Lopez - Thirlwall 2015). ${ }^{9}$

9 The data was also disaggregated between low-income, lower-middle income, and upper-middle-income countries and also between the continents of Africa, Asia, and Latin America, but only the aggregate results are presented here. 
Figure 1 shows the relationship between GDP growth and manufacturing output growth (Kaldor's first law).

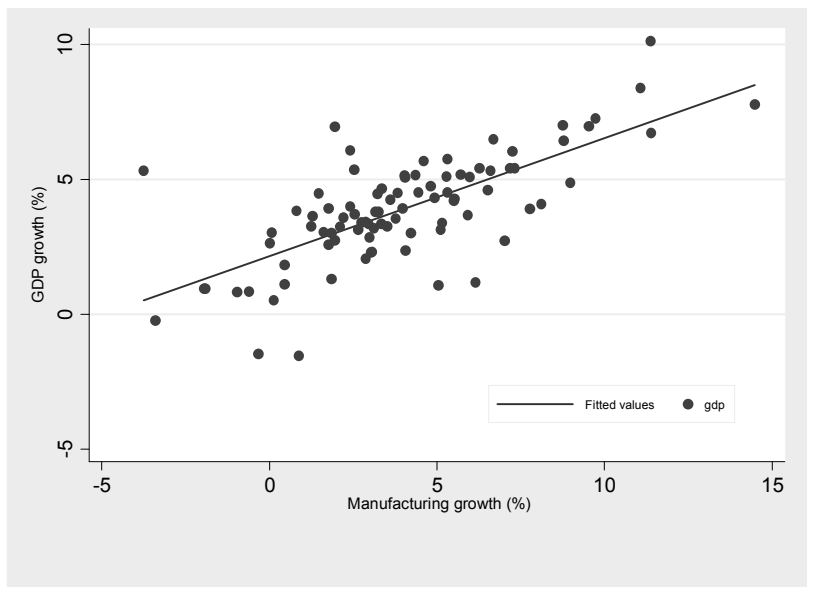

Figure 1. Association between GDP growth and manufacturing growth, 1990-2011

The estimated equation is ( $\mathrm{t}$-values in brackets):

$$
\begin{aligned}
g_{g d p}= & 2.16+0.43 g_{m} \quad: \quad r^{2}=0.50 . \\
& (9.07) \quad(9.43)
\end{aligned}
$$

Figure 2 shows the relation between manufacturing output growth and export growth.

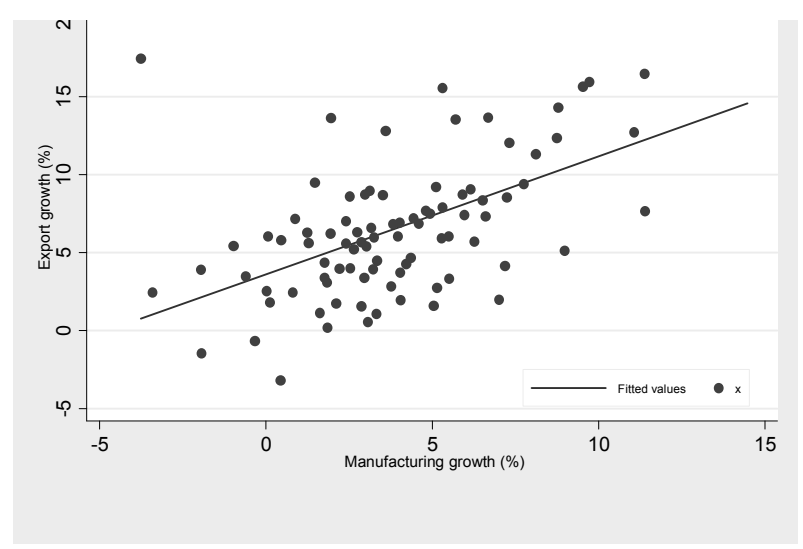

Figure 2. Association between export growth and manufacturing growth, 1990-2011 
The estimated equation is

$$
X=3.59+0.75 g_{m}: r^{2}=0.30 .
$$

The strong positive relation should occasion no surprise. For any given growth of world income, the growth of exports will depend on the structure of production and the income elasticity of demand for different products. Export growth is endogenous in this sense and is likely to be related to the growth of manufacturing output since all manufactures are potentially tradable. Primary products are also potentially tradable, but they do not have the same production and demand characteristics. Their demand growth in international trade is low (Engel's Law). Some services are tradable, but many are not, and their income elasticity in world markets is not likely to be as high as for medium- and high-technology manufactured goods.

Figure 3 shows the link between export growth and GDP growth. The estimated equation by two-stage least squares is

$$
g_{\text {gdp }}=0.09+0.57 \mathrm{x} \quad: \quad r^{2}=0.50 \text {. }
$$

There are three major reasons for expecting a priori a close link between export growth and GDP growth. First, there is the neoclassical supply-side argument which focuses on the static and dynamic gains from trade and the externalities that the export sector can confer on the non-export sector and the rest of the economy (Feder 1983). Exports also allow the import of inputs and investment

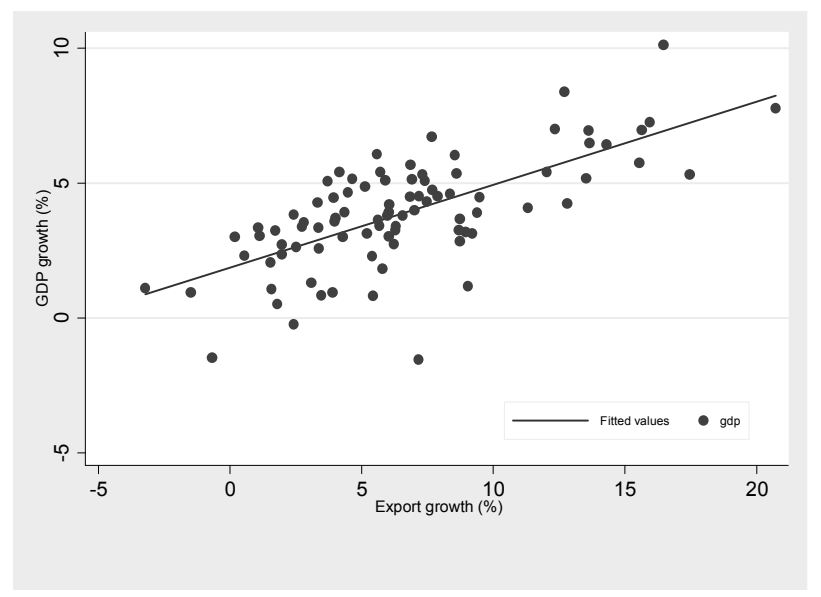

Figure 3. Association between GDP growth and export growth, 1990-2011 
goods that may be more productive than domestic resources, thus increasing the supply capacity of the economy. Secondly, if domestic demand is constrained by a shortage of foreign exchange, faster export growth will help relax that constraint. All components of demand have an import content which need to be paid for, and only exports can do so. Exports are a unique component of demand in that respect (McCombie 1985). Thirdly, export growth may set off a virtuous circle of growth, as outlined earlier.

The results of this research across a wide sample of developing countries support the work of Hausmann et al. (2007) on "What You Export Matters" which shows a close association between what they call EXPY and growth rate differences across countries. EXPY is a weighted average of what they call PRODY which measures the income level that each good produced is associated with. If a low-income country (like China) produces high-tech goods associated with high-income countries, it will have a high PRODY and a high EXPY and will grow fast - as China has done. What this close association between EXPY and GDP growth is picking up is the higher income elasticity of demand for high technology manufactured goods.

\section{CONCLUSION}

Kaldor was one of the most original, inspiring, and controversial economists of his day. His many contributions to economic theory and applied analysis will ensure his place in the history of economic thought. It is perhaps a matter of regret that he never wrote a grand Treatise in the tradition of Smith, Mill, Ricardo, Marx, or Marshall. He did not lack the vision, intellect, or ability to write, but he succumbed to the temptation of becoming involved in too many projects at the same time, and never found the time to sit down for long concentrated periods which such a magnum opus requires. His nine volumes of Collected Essays (1960a, 1960b, 1964a, 1964b, 1978a, 1978b, 1980a, 1980b, 1989) are some substitute, however; they give a coherence to his work, and provide a lasting monument to the man. My own debt to him will be his contribution to the applied economics of growth, and his stress on the importance of structure and demand in understanding the different levels of development, and differences in the growth performance, of countries. His 1966 "Inaugural Lecture" started the break with one-good models of the orthodox neoclassical mainstream, and now occupies centre-stage in serious discussions of how to accelerate the progress of developing countries (Szirmai et al. 2013). 


\section{REFERENCES}

Arrow, K. (1962): The Economic Implications of Learning by Doing. Review of Economic Studies, 29(3): 155-173.

Dixon, R. - Thirlwall, A. P. (1975): A Model of Regional Growth Rate Differences on Kaldorian Lines. Oxford Economic Papers, 27(2): 201-214.

Feder, G. (1983): On Exports and Economic Growth. Journal of Development Economics, 12(112): $59-73$.

Hansen, J. - Zhang, J. (1996): A Kaldorian Approach to Regional Economic Growth in China. Applied Economics, 28(6): 679-685.

Harrod, R. (1933): International Economics. London: Macmillan.

Hausmann, R. - Hwang, J. - Rodrik, D. (2007): What You Export Matters. Journal of Economic Growth, 12(1): 1-25.

Kaldor, N. (1932): The Economic Situation of Austria. Harvard Business Review, October.

Kaldor, N. (1934a): The Equilibrium of the Firm. Economic Journal, March.

Kaldor, N. (1934b): Mrs Robinson's ‘Economics of Imperfect Competition'. Economica, August.

Kaldor, N. (1935): Market Imperfections and Excess Capacity. Economica, February.

Kaldor, N. (1937): The Controversy on the Theory of Capital. Econometrica, July.

Kaldor, N. (1939a): Welfare Propositions in Economics and Interpersonal Comparisons of Utility. Economic Journal, September.

Kaldor, N. (1939b): Speculation and Economic Stability. Review of Economic Studies, October.

Kaldor, N. (1940): A Model of the Trade Cycle. Economic Journal, March.

Kaldor, N. (1955): An Expenditure Tax. London: Allen \& Unwin.

Kaldor, N. (1956): Alternative Theories of Distribution. Review of Economic Studies, 23(2): 83-100.

Kaldor, N. (1957): A Model of Economic Growth. Economic Journal, December.

Kaldor, N. (1960a): Essays on Value and Distribution. London: Duckworth.

Kaldor, N. (1960b): Essays on Economic Stability and Growth. London: Duckworth.

Kaldor, N. (1961): Capital Accumulation and Economic Growth. In: Lutz, F. (ed.): The Theory of Capital. London: Macmillan.

Kaldor, N. (1964a): Essays on Economic Policy 1. London: Duckworth.

Kaldor, N. (1964b): Essays on Economic Policy 2. London: Duckworth.

Kaldor, N. (1966): Causes of the Slow Rate of Growth of the United Kingdom. Cambridge: Cambridge University Press.

Kaldor, N. (1967): Strategic Factors in Economic Development. Ithaca, New York: Cornell University Press.

Kaldor, N. (1970a): The Case for Regional Policies. Scottish Economic Journal, November.

Kaldor, N. (1970b): The New Monetarism. Lloyds Bank Review, July.

Kaldor, N. (1972): The Irrelevance of Equilibrium Economics. Economic Journal, December.

Kaldor, N. (1975): What is Wrong with Economic Theory? Quarterly Journal of Economics, August.

Kaldor, N. (1978a): Further Essays on Economic Theory. London: Duckworth.

Kaldor, N. (1978b): Further Essays on Applied Economics. London: Duckworth.

Kaldor, N. (1979): Equilibrium and Growth Theory. In: Boskin, M. (ed.): Economics and Human Welfare: Essays in Honour of Tibor Scitovsky. Academic Press, pp. 273-292.

Kaldor, N. (1980a): Memorandum of Evidence on Monetary Policy to the Select Committee on the Treasury and Civil Service. HMSO, July $17^{\text {th }}$.

Kaldor, N. (1980b): Reports on Taxation 1. London: Duckworth.

Kaldor, N. (1980c): Reports on Taxation 2. London: Duckworth. 
Kaldor, N. (1981): The Role of Increasing Returns, Technical Progress and Cumulative Causation in the Theory of International Trade and Economic Growth. Economie Appliquee, XXX1V(4).

Kaldor, N. (1982): The Scourge of Monetarism. Oxford: Oxford University Press.

Kaldor, N. (1983): The Economic Consequences of Mrs Thatcher. London: Duckworth.

Kaldor, N. (1985): Economics without Equilibrium. University College Cardiff Press.

Kaldor, N. (1986a): Recollections of an Economist. Banca Nazionale del Lavoro Quarterly Review, March.

Kaldor, N. (1986b): Limits on Growth. Oxford Economic Papers, July.

Kaldor, N. (1989): Further Essays of Economic Theory and Policy (ed. by Targetti, F. - Thirlwall, A. P.). London: Duckworth.

Kaldor, N. (1996): Causes of Growth and Stagnation in the World Economy (The Raffaele Mattioli Lectures, ed. by Targetti, F. - Thirlwall, A. P.). Cambridge: Cambridge University Press.

Kaldor, N. - Mirrlees, J. (1962): A New Model of Economic Growth. Review of Economic Studies, June.

King, J. (2009): Nicholas Kaldor. London: Palgrave-Macmillan.

Kornai, J. (2007): By Force of Thought (Irregular Memoirs of an Intellectual Journey). Cambridge (MA): MIT Press.

Libanio, G. - Moro, S. (2006): Manufacturing Industry and Economic Growth in Latin America. A Kaldorian Approach. Manuscript. Federal University of Minas Gerais, Brazil.

McCombie, J. S. L. (1985): Economic Growth, the Harrod Foreign Trade Multiplier and the Hicks Super Multiplier. Applied Economics, 17(1): 55-72.

McCombie, J. S. L. - Pugno, M. - Soro, B. (eds) (2003): Productivity Growth and Economic Performance: Essays on Verdoorn's Law. London: Palgrave-Macmillan.

Mihalyi, P. (2017): Kaldor and Kornai on Economics without Equilibrium - Two Life Courses. Acta Oeconomica, 67 (Special Issue), 47-66.

Mommen, A. (2017): Káldor's versus Varga's - The Hungarian Three-Year Economic Reconsruction Plan of 1947. Acta Oeconomica, 67 (Special Issue): 157-173.

Myrdal, G. (1957): Economic Theory and Underdeveloped Regions. London: Duckworth.

Necmi, S. (1999): Kaldor's Growth Analysis Revisited. Applied Economics, 31(5): 653-660.

Offer, A. - Söderberg, G. (2016): The Nobel Factor. The Prize in Economics, Social Democracy, and the Market Turn. Princeton and Oxford: Oxford University Press.

Pacheco-Lopez, P. - Thirlwall, A. P. (2014): A New Interpretation of Kaldor's First Law of Growth in an Open Developing Economy. Review of Keynesian Economics, 2(3): 384-398.

Prebisch, R. (1959): Commercial Policy in the Underdeveloped Countries. American Economic Review, Papers and Proceedings, 49(2) May.

Priewe, J. (2012): European Imbalances and the Crisis of the European Monetary Union. In: Herr, H. - Niechoj, T. - Thomasberger, C. - Truger, A. - van Treek, T. (eds): From Crisis to Growth? The Challenge of Debt and Indebtedness. Marburg: Metropolis, pp. 331-360

Szirmai, A. - Naude, W. - Alcorta, L. (eds) (2013): Pathways to Industrialisation in the $21^{\text {st }}$ Century. Oxford: Oxford University Press.

Targetti, F. (1985): Growth and the Terms of Trade: A Kaldorian Two Sector Model. Metroeconomica, 36(1): 79-96.

Targetti, F. (1992): Nicholas Kaldor. Oxford: Clarendon Press.

Thirlwall, A. P. (1980): Regional Problems are Balance of Payments Problems. Regional Studies, 14(5): 419-425.

Thirlwall, A. P. (1982): The Harrod Trade Multiplier and the Importance of Export-Led Growth. Pakistan Journal of Applied Economics, 1(1): 1-21. 
Thirlwall, A. P. (1986): A General Model of Growth and Development on Kaldorian Lines. Oxford Economic Papers, 38(2): 199-219.

Thirlwall, A. P. (1987): Nicholas Kaldor. New York: New York University Press.

Thirlwall, A. P. - Dixon, R. (1979): A Model of Export-Led Growth with a Balance of Payments Constraint. In: Bowers, J. (ed.): Inflation, Development and Integration: Essays in Honour of A. J. Brown. Leeds: Leeds University Press. pp. 173-192.

Verdoorn, P. J. (1949): Fattori che regalano lo sviluppo della produttivita del lavoro (On the Factors Determining the Growth of Labour Productivity). L'Industria, 1: 3-10.

Wells, H. - Thirlwall, A. P. (2003): Testing Kaldor's Growth Laws across the Countries of Africa. African Development Review, 15(2-3): 89-105.

Young, A. A. (1928): Increasing Returns and Economic Progress. Economic Journal, 38(152): $527-542$. 